\title{
NOTCH1 Pathway is Involved in Polyhexamethylene Guanidine-Induced Humidifier Disinfectant Lung Injuries
}

\author{
Eun Lee', Mi Jin Kang ${ }^{2}$, Jeong-Hyun Kim³ ${ }^{3}$, Seung-Hwa Lee ${ }^{2}$, So-Yeon Lee ${ }^{4}$, Hyun-Ju Cho ${ }^{5}$, Jisun Yoon ${ }^{6}$, \\ Sungsu Jung ${ }^{7}$, Yangsoon Park ${ }^{8}$, Dong Kyu Oh${ }^{9}$, Sang-Bum Hong ${ }^{10}$, and Soo-Jong Hong ${ }^{4}$ \\ ${ }^{1}$ Department of Pediatrics, Chonnam National University Hospital, Chonnam National University Medical School, Gwangju; \\ ${ }^{2}$ Asan Medical Center, Asan Institute for Life Sciences, Environmental Health Center, Seoul; \\ ${ }^{3}$ Department of Medicine, University of Ulsan Collage of Medicine, Seoul; \\ ${ }^{4}$ Department of Pediatrics, Childhood Asthma Atopy Center, Environmental Health Center, Asan Medical Center, \\ University of Ulsan College of Medicine, Seoul; \\ ${ }^{5}$ Department of Pediatrics, International St. Mary's hospital, Catholic Kwandong University College of Medicine, Incheon; \\ ${ }^{6}$ Department of Pediatrics, Mediplex Hospital, Incheon; \\ ${ }^{7}$ Department of Pediatrics, Pusan National University Yangsan Hospital, Yangsan; \\ ${ }^{8}$ Department of Pathology, Asan Medical Center, University of Ulsan College of Medicine, Seoul; \\ ${ }^{9}$ Department of Pulmonary and Critical Care Medicine, Asan Medical Center, Seoul; \\ ${ }^{10}$ Department of Pulmonary and Critical Care Medicine, Asan Medical Center, University of Ulsan College of Medicine, Seoul, Korea.
}

An outbreak of fatal humidifier disinfectant lung injuries (HDLI) occurred in Korea. Human studies on mechanisms underlying HDLI have yet to be conducted. This study aimed to investigate methylation changes and their potential role in HDLI after exposure to HDs containing polyhexamethylene guanidine-phosphate. DNA methylation analysis was performed in blood samples from 10 children with HDLI and 10 healthy children using Infinium Human MethylationEPIC BeadChip. Transcriptome analysis was performed using lung tissues from 5 children with HDLI and 5 controls. Compared to healthy controls, 92 hypo-methylated and 79 hyper-methylated CpG sites were identified in children with HDLI at the statistical significance level of $|\Delta \beta|>0.2$ and $p<0.05$. NOTCH1 was identified as a candidate network hub gene in cases. NOTCH1 transcripts significantly increased in lung tissues from HDLI cases compared to unexposed controls $(p=0.05)$. NOTCH1 may play an important role in pulmonary fibrosis of HDLI.

Key Words: Humidifier disinfectant, pulmonary fibrosis, $\mathrm{NOTCH1}$, methylation, polyhexamethylene guanidine

An outbreak of fatal lung injuries occurred in Korea between early 2000 and 2011, characterized by rapidly progressing respi-

\footnotetext{
Received: September 23, 2019 Revised: November 29, 2019

Accepted: December 26, 2019

Corresponding author: Soo-Jong Hong, MD, PhD, Department of Pediatrics, Childhood Asthma and Atopy Center, Environmental Health Center, Asan Medical Center, University of Ulsan College of Medicine, 88 Olympic-ro 43-gil, Songpa-gu, Seoul 05505, Korea.

Tel: 82-2-3010-3379, Fax: 82-2-473-3725, E-mail: sjhong@amc.seoul.kr

-The authors have no potential conflicts of interest to disclose.

(C) Copyright: Yonsei University College of Medicine 2020

This is an Open Access article distributed under the terms of the Creative Commons Attribution Non-Commercial License (https://creativecommons.org/licenses/ by-nc/4.0) which permits unrestricted non-commercial use, distribution, and reproduction in any medium, provided the original work is properly cited.
}

ratory failure with lung fibrosis, extensive air leak syndrome in many cases, a lack of responsiveness to any treatment, and high mortality rate. ${ }^{1-5}$ This fatal interstitial lung disease (ILD) was distinct from previously identified ILDs in terms of clinical course as well as radiologic and pathologic findings; therefore, it was considered to be idiopathic. ${ }^{1,2}$ Toxic chemicals, including polyhexamethylene guanidine (PHMG), in humidifier disinfectants (HDs) were subsequently identified as the cause. ${ }^{1,2}$ The unique features of this fatal lung disease raised questions regarding the distinct mechanisms underlying the disorder. ${ }^{6}$ However, there has been no report on the mechanisms underlying HD-associated lung injuries (HDLI) in humans. As altered DNA methylation is associated with development of idiopathic pulmonary fibrosis,${ }^{6,7}$ we investigated whether DNA methylation plays a 
Table 1. Clinical Characteristics of the Study Population

\begin{tabular}{|c|c|c|c|c|}
\hline \multirow{2}{*}{ Mean $\pm S D$ or number } & \multicolumn{2}{|c|}{ Methylation study from blood samples } & \multicolumn{2}{|c|}{ Transcriptome study with lung tissues } \\
\hline & Controls & Children with HDLI & Controls & Children with HDLI \\
\hline Number & 10 & 10 & 5 & 5 \\
\hline Age at sample collection (yr) & $7.0 \pm 0.6$ & $11.4 \pm 3.6$ & $9.0 \pm 2.4$ & $1.8 \pm 0.8$ \\
\hline Age at diagnosis of HDLI (month) & NA & $35.4 \pm 1.8$ & NA & $30.2 \pm 9.5$ \\
\hline Sex, male:female & $7: 3$ & $7: 3$ & $2: 3$ & $2: 3$ \\
\hline Dyspnea at diagnosis & $0 / 10$ & $9 / 10$ & $0 / 5$ & $5 / 5$ \\
\hline Pneumothorax during illness & $0 / 10$ & $4 / 10$ & $0 / 5$ & $5 / 5$ \\
\hline Oxygen need & $0 / 10$ & $9 / 10$ & $0 / 5$ & $5 / 5$ \\
\hline Ventilator care & $0 / 10$ & $2 / 10$ & $0 / 5$ & $0 / 5$ \\
\hline Mortality & $0 / 10$ & $0 / 10$ & $0 / 5$ & $0 / 5$ \\
\hline
\end{tabular}

HDLI, humidifier disinfectant lung injuries; NA, not applicable.

role in HDLI using human samples.

Blood samples from 10 children with HDLI and 10 healthy control children with no exposure to HDs were used to analyze methylation profiles. Clinical characteristics of the study population are summarized in Table 1. The mean age at diagnosis of HDLI was 35.4 months (range, 12-81 months) and blood samples for methylation analysis were obtained at a mean age of 11.4 years (range, 7- 15 years). Male-to-female rate was 7:3. None of the children in sex-matched control group had any respiratory diseases and their mean age was 7 years. DNA extracted from the peripheral blood mononuclear cells of each subject was analyzed using Infinium Human MethylationEPIC BeadChip (Illumina, San Diego, CA, USA). For quality check (QC) of the methylation data, beta-mixture quantile normalization, and Pearson's correlation (range: $-1 \leq r \leq 1$ ) for reproducibility between samples were performed. For QC of the transcriptome data, all data were normalized with the robust multi-average method implemented in in Affymetrix ${ }^{\mathbb{R}}$ Power Tools (Thermo Fisher Scientific, Waltham, MA, USA). Statistical significance for differentially methylated CpG sites was set at $|\Delta \beta|>0.2$ and $p<0.05$ using a t-test. Ingenuity ${ }^{\circledR}$ Pathway Analysis (IPA, Ingenuity Systems, Redwood City, CA, USA) was used to represent the functional networks of genes containing differentially methylated CpG sites. Transcriptome analysis was performed using lung tissues from five pediatric patients with HDLI and five control children. Lung tissue was obtained from children with no abnormal lung lesions from Bio-Resource Center at Asan Medical Center to form a control group. The Institutional Review Board of Asan Medical Center reviewed and approved the study protocol (IRB No. 2016-0885).

A total of 171 CpG loci (79 hypermethylated, 92 hypomethylated) showed significantly differential methylation patterns in children with HDLI compared to the controls (Fig. 1A), with a distinctive clustering observed between the two groups (Fig. 1B) (Table 2). The top 25 hypomethylated and 25 hypermethylated CpG loci are listed in Table 2. SYT8 cg09575189 showed the highest hypomethylation level $(|\Delta \beta|=0.433, p=0.003)$, whereas cg26786615 (chr16: 86593603) had the highest hypermethylation level $(|\Delta \beta|=0.519, p=0.0006)$. However, there are a few func- tional studies of these two genes and no reports in existing literature that provide any clues to the associations between them and fibrosis and/or lung diseases. Potential upstream and downstream regulators of NOTCH1 based on IPA network analysis and its signaling (https://www.rndsystems.com/pathwyas/notchsignaling-pathway) are described in Table 3.

NOTCH1 cg14065526 showed a significant degree of hypomethylation $(|\Delta \beta|=0.304, p=0.016)$. In further network analysis of the genes containing differently methylated CpG sites, "cancer, organismal injury and abnormalities, reproductive system disease (score $=41$ )" was identified as the top network for HDLI, indicating NOTCH1 as a hub gene (Fig. 1C). The cg14065526 (chr9: 139406352) of NOTCH1 showed a significantly hypomethylated level $(|\Delta \beta|=0.304, p=0.016)$. NOTCH1 transcripts from lung tissues were significantly elevated in HDLI cases compared to unexposed controls ( $p=0.05$, each group $n=5$ ) (Fig. 1D).

Our present findings from methylation and transcriptome analysis of human blood and lung tissues have identified that $\mathrm{NOTCHl}$ is involved in the pathogenesis of HDLI. This is the first study to investigate DNA methylation changes and network analyses combined with transcriptomics in pediatric patients with HDLI, which may partially explain the underlying mechanisms of HDLI.

Although NOTCH1 may be common to the mechanisms of other types of ILDs, ${ }^{8}$ the results of our current analysis suggest that it also plays a central role in the mechanism of HDLI. Notchl is involved in angiogenesis, abnormal remodeling of vessels, and mucus hypersecretion, and thereby is associated with pathogenesis of diverse lung diseases. ${ }^{9}$ The apoptosis of bronchial epithelial cells following exposure to toxic chemicals affects the clearance of apoptotic debris combined with lung fibrosis. ${ }^{10}$ The overexpression of NOTCH1, which is related to its gene hypomethylation, as shown in this study, promotes the differentiation of myofibroblasts, which is a critical step in pulmonary fibrosis. ${ }^{3} \mathrm{NOTCH} 1$ has been identified to be involved in bleomycin-induced lung diseases and paraquat poisoning, for which the main mechanism is pulmonary fibrosis. ${ }^{11,12}$ The results of previous reports and our present findings provide strong evidence for the involvement of $\mathrm{NOTCH} 1$ in the pathogenesis of 


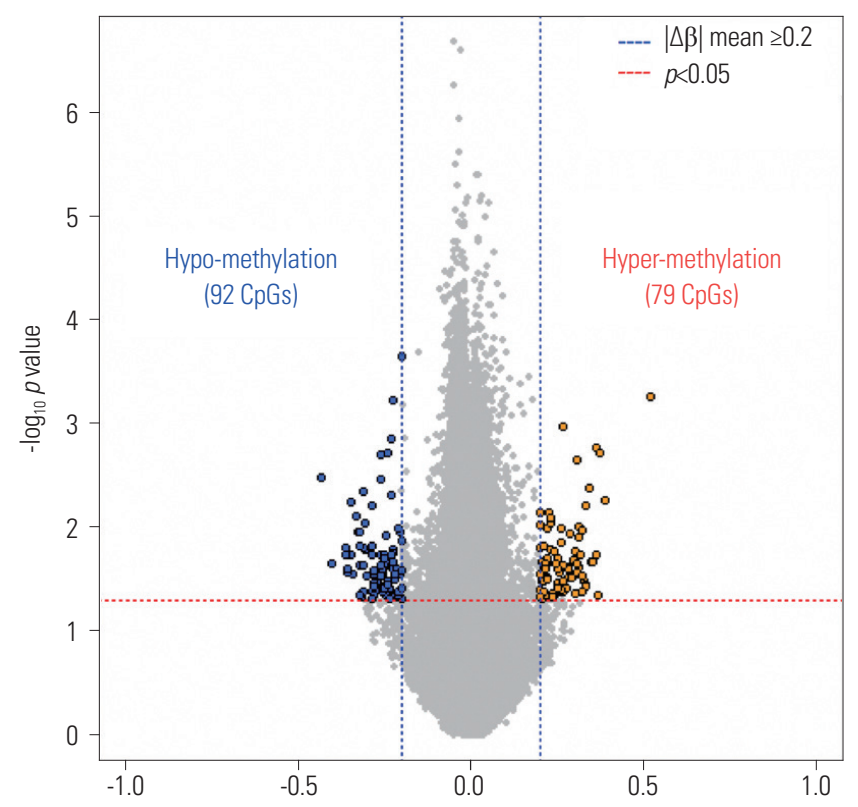

A

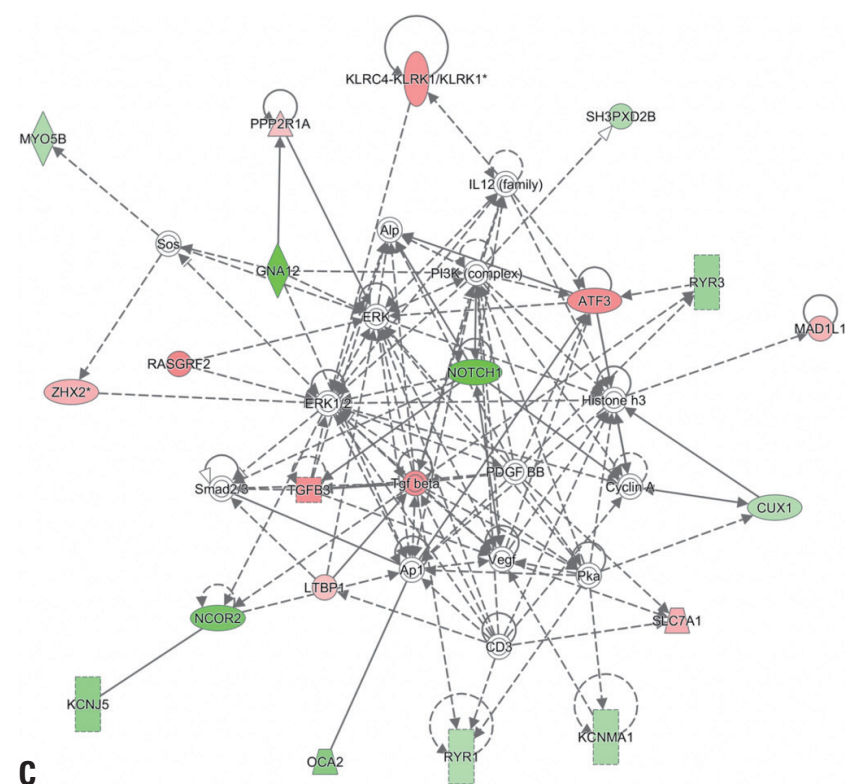

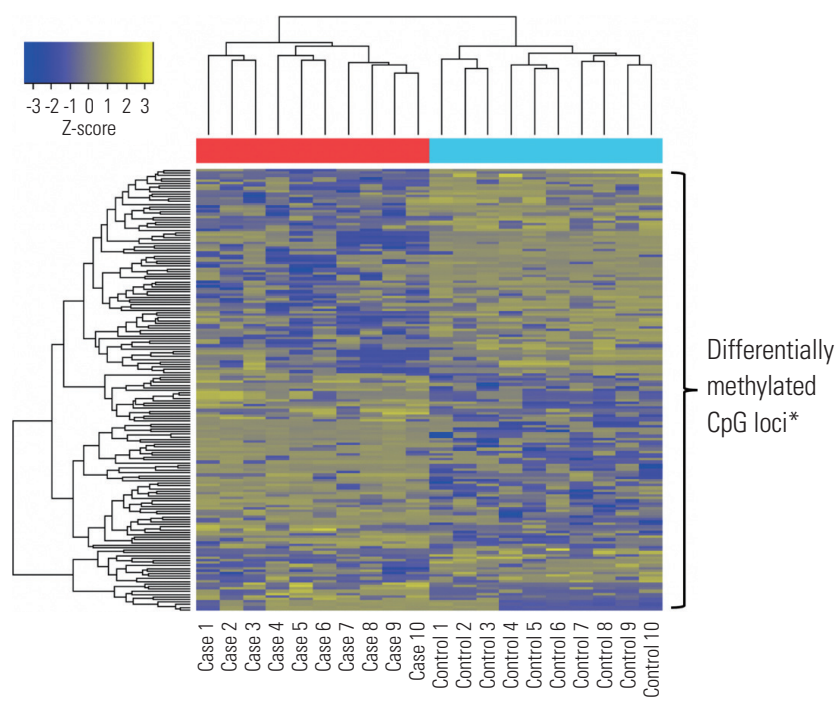

B

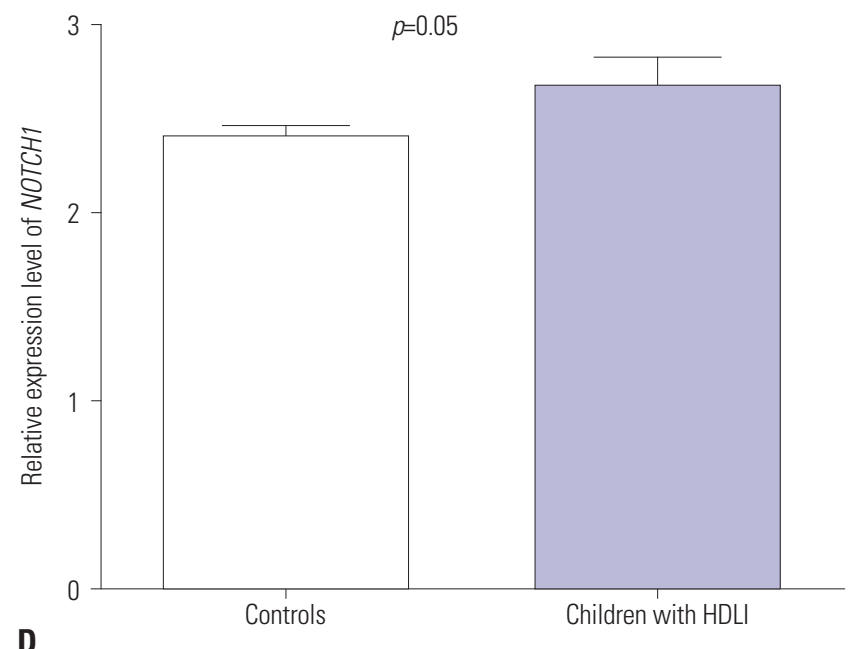

Fig. 1. Results of methylation, network, and NOTCH1 expression analysis in pediatric HDLI cases. (A) Volcano plot of differentially methylated CpG sites. (B) Heatmap of differentially methylated CpG sites between children with humidifier disinfectant associated lung injuries and unexposed healthy controls. Differentially methylated $\mathrm{CpG}$ loci indicated by asterisk. (C) The top network of differentially methylated $\mathrm{CpG}$ sites was found to be "cancer, organismal injury and abnormalities, reproductive system disease" and was derived from genes containing hyper-/hypo-methylated CpG sites associated with HDLI. (D) The transcriptional expression of NOTCH1 between HDLI cases and the control group ( $p=0.05$, $\mathrm{t}$-test, nonparametric methods were applied, and no correction for multiple testing was done due to the small sample size of each group, $n=5$ for each group). HDLI, humidifier disinfectant lung injuries.

fatal fibrotic lung diseases and give new insights into the possible mechanisms of lung injuries caused by inhalation of unidentified but harmful chemicals that are commonly used.

The inhalation of toxic chemicals damages the epithelial lining in the airway, initiating a series of processes including disruption of epithelial lining, alterations of diverse mediators and chemokine levels, and induction of epithelium-to-mesenchymal transition (EMT). ${ }^{13}$ NOTCH1 regulates EMT through vari- ous signaling factors, such as TGF- $\beta$, NF- $\kappa \mathrm{B}$, and $\beta$-catenin. ${ }^{10}$ It has been reported that exposure to PHMG phosphate can induce EMT in a dose-dependent manner. ${ }^{14}$ A previous study identified that PHMG could induce EMT through the Akt/Notch signaling pathway. ${ }^{15}$ This prior evidence, in combination with our current data, further supports the notion that $\mathrm{NOTCH1}$ plays a role in the pathogenesis of HDLI via EMT following exposure to HDs that contain PHMG. 
Table 2. Top 25 Hypomethylated and Top 25 Hypermethylated Sites Showing Significantly Different Levels in Pediatric Patients with HDLI Compared to Unexposed Healthy Control Children

\begin{tabular}{|c|c|c|c|c|c|c|c|c|c|}
\hline \multirow{2}{*}{$\begin{array}{c}\text { Methylation } \\
\text { type }^{*}\end{array}$} & \multirow{2}{*}{ Illumina ID } & \multirow{2}{*}{ Chr. } & \multirow{2}{*}{ CpG coordinate } & \multirow{2}{*}{ (Nearest) gene } & \multirow{2}{*}{ Position $^{\dagger}$} & \multicolumn{2}{|c|}{ Beta value (average) } & \multirow{2}{*}{$\Delta \beta$} & \multirow{2}{*}{$p$ value } \\
\hline & & & & & & Patients (n=10) & Controls $(n=10)$ & & \\
\hline Нypo- & cg09575189 & 11 & 1855561 & SYTO & TSS200 & 0.376 & 0.808 & -0.433 & 0.003 \\
\hline Нуро- & cg05751055 & 6 & 33036504 & HLA-DPA1 & Gene body & 0.520 & 0.922 & -0.402 & 0.022 \\
\hline Нypo- & cg11437465 & 6 & 33036958 & HLA-DPA1 & Gene body & 0.442 & 0.806 & -0.364 & 0.018 \\
\hline Нypo- & cg05340866 & 7 & 148032668 & CNTNAP2 & Gene body & 0.200 & 0.563 & -0.363 & 0.016 \\
\hline Нypo- & $\operatorname{cg} 07474670$ & 12 & 124831017 & NCOR2 & Gene body & 0.357 & 0.714 & -0.357 & 0.027 \\
\hline Нypo- & cg07791065 & 6 & 113786051 & (LINC02518) & & 0.370 & 0.726 & -0.356 & 0.025 \\
\hline Нypo- & $\operatorname{cg} 13318082$ & 1 & 19669688 & $C A P Z B$ & Gene body & 0.616 & 0.965 & -0.348 & 0.006 \\
\hline Нypo- & cg05526809 & 4 & 1309416 & MAEA & Gene body & 0.508 & 0.855 & -0.346 & 0.018 \\
\hline Нypo- & cg05554406 & 7 & 2834869 & GNA12 & Gene body & 0.419 & 0.760 & -0.340 & 0.028 \\
\hline Нуро- & cg20976286 & 15 & 28054345 & OCA2 & Gene body & 0.405 & 0.735 & -0.330 & 0.008 \\
\hline Нypo- & cg06378142 & 19 & 50119633 & PRR12 & Gene body & 0.409 & 0.737 & -0.328 & 0.011 \\
\hline Нуро- & $\operatorname{cg} 11074353$ & 6 & 153066907 & (VIP) & & 0.488 & 0.811 & -0.323 & 0.023 \\
\hline Нуро- & cg20981163 & 6 & 33049983 & HLA-DPB1 & Gene body & 0.369 & 0.691 & -0.323 & 0.015 \\
\hline Нуро- & cg12858166 & 6 & 33033176 & HLA-DPA1 & 3'UTR & 0.415 & 0.738 & -0.322 & 0.045 \\
\hline Нуро- & cg24906015 & 2 & 58482767 & (FANCL) & & 0.540 & 0.862 & -0.321 & 0.011 \\
\hline Нуро- & cg07846874 & 7 & 11568529 & THSD7A & Gene body & 0.512 & 0.830 & -0.318 & 0.048 \\
\hline Нуро- & $\operatorname{cg} 17635970$ & 8 & 133117602 & HHLA1 & TSS200 & 0.548 & 0.861 & -0.313 & 0.023 \\
\hline Нуро- & cg10978613 & 8 & 117473031 & (LINC00536) & & 0.561 & 0.874 & -0.313 & 0.041 \\
\hline Нуро- & cg19484093 & 4 & 119990940 & (SYNP02) & & 0.417 & 0.727 & -0.310 & 0.016 \\
\hline Нуро- & cg16715186 & 22 & 45981385 & FBLN1 & Gene body & 0.522 & 0.832 & -0.309 & 0.004 \\
\hline Нypo- & cg16776298 & 1 & 4784556 & AJAP1 & Gene body & 0.499 & 0.805 & -0.306 & 0.009 \\
\hline Нуро- & cg14065526 & 9 & 139406352 & NOTCH1 & Gene body & 0.168 & 0.473 & -0.304 & 0.016 \\
\hline Нypo- & cg17348244 & 7 & 786861 & HEATR2 & Gene body & 0.624 & 0.926 & -0.303 & 0.029 \\
\hline Нуро- & cg07336544 & 10 & 79194347 & KCNMA1 & Gene body & 0.430 & 0.717 & -0.287 & 0.019 \\
\hline Нуро- & cg04869491 & 15 & 33757740 & RYR3; RYR3 & Gene body & 0.643 & 0.929 & -0.286 & 0.015 \\
\hline Hyper- & cg04105547 & 16 & 965857 & LMF1 & Gene body & 0.557 & 0.254 & 0.303 & 0.043 \\
\hline Hyper- & cg07093060 & 3 & 174092757 & (NAALADL2) & & 0.751 & 0.447 & 0.304 & 0.017 \\
\hline Hyper- & cg18932722 & 12 & 94987650 & TMCC3 & 5'UTR & 0.864 & 0.557 & 0.307 & 0.022 \\
\hline Hyper- & cg06264089 & 12 & 10563947 & KLRC4-KLRK1 & TSS1500 & 0.686 & 0.378 & 0.307 & 0.002 \\
\hline Hyper- & cg04263740 & 7 & 65375514 & VKORC1L1 & Gene body & 0.737 & 0.430 & 0.308 & 0.027 \\
\hline Hyper- & cg01359658 & 7 & 2426868 & (EIF3B) & & 0.633 & 0.321 & 0.312 & 0.010 \\
\hline Hyper- & $\operatorname{cg} 27114706$ & 12 & 92527244 & LOC256021 & Gene body & 0.778 & 0.465 & 0.312 & 0.012 \\
\hline Hyper- & cg01235375 & 2 & 66836203 & LOC100507073 & Gene body & 0.804 & 0.490 & 0.315 & 0.024 \\
\hline Hyper- & cg13910001 & 20 & 31622082 & BPIFB6 & Exon & 0.453 & 0.135 & 0.319 & 0.018 \\
\hline Hyper- & $\operatorname{cg} 17155524$ & 4 & 2305734 & ZFYVE28 & Gene body & 0.747 & 0.426 & 0.321 & 0.030 \\
\hline Hyper- & cg18828306 & 11 & 17555864 & USH1C & Gene body & 0.605 & 0.284 & 0.321 & 0.041 \\
\hline Hyper- & cg05971102 & 2 & 3753297 & DCDC2C & Gene body & 0.616 & 0.293 & 0.323 & 0.011 \\
\hline Hyper- & cg01463139 & 1 & 158435277 & OR10K1 & TSS200 & 0.756 & 0.429 & 0.327 & 0.033 \\
\hline Hyper- & cg08880082 & 14 & 90165664 & (FOXN3) & & 0.876 & 0.542 & 0.334 & 0.036 \\
\hline Hyper- & cg15570860 & 11 & 8986840 & TMEM9B; TMEM9B-AS1 & TSS1500; body & 0.701 & 0.368 & 0.334 & 0.038 \\
\hline Hyper- & cg05961492 & 22 & 47459539 & TBC1D22A & Gene body & 0.467 & 0.133 & 0.334 & 0.006 \\
\hline Hyper- & $\operatorname{cg} 14080585$ & 20 & 60639721 & TAF4 & Exon & 0.550 & 0.208 & 0.342 & 0.004 \\
\hline Hyper- & cg01886237 & 4 & 122378794 & (QRFPR) & & 0.675 & 0.329 & 0.346 & 0.022 \\
\hline Hyper- & cg04234412 & 22 & 24373322 & LOC391322 & Gene body & 0.834 & 0.481 & 0.353 & 0.022 \\
\hline Hyper- & cg21193926 & 14 & 76443578 & TGFB3 & Gene body & 0.694 & 0.331 & 0.363 & 0.018 \\
\hline Hyper- & cg04531182 & 12 & 10563981 & KLRC4-KLRK1 & TSS1500 & 0.619 & 0.256 & 0.363 & 0.002 \\
\hline Hyper- & cg25099095 & 6 & 156954565 & (ARID1B) & & 0.735 & 0.367 & 0.369 & 0.045 \\
\hline Hyper- & cg08041188 & 12 & 10564015 & KLRC4-KLRK1 & TSS1500 & 0.698 & 0.326 & 0.372 & 0.002 \\
\hline Hyper- & cg11547201 & 5 & 80501337 & RASGRF2; RNU5E; RNU5D & Body; TSS200; TSS200 & 0.866 & 0.477 & 0.389 & 0.005 \\
\hline Hyper- & $\operatorname{cg} 26786615$ & 16 & 86593603 & (MTHFSD) & & 0.779 & 0.261 & 0.519 & 0.0006 \\
\hline
\end{tabular}

HDLI, humidifier disinfectant lung injuries; TSS, transcription start site; UTR, untranslated region.

${ }^{*}$ Hyper- and hypo- indicate the methylation levels of patients compared to controls, ${ }^{\dagger}$ TSS200 and TSS1500 indicate the distance within 200 bp and 1500 bp from TSS, respectively. 
Table 3. Gene Expression of Potential Upstream and Downstream Regulators of NOTCH1 in Formalin-Fixed, Paraffin-Embedded Lung Tissue Specimens from Children with HDLI and the Control Group

\begin{tabular}{|c|c|c|c|c|}
\hline Category & Gene & mRNA accession & Fold change & $p$ value \\
\hline \multicolumn{5}{|l|}{ Upstream regulators } \\
\hline & DAP3 & NM_001199849 & 1.41 & 0.017 \\
\hline & ACTN1 & NM_001102 & 1.56 & 0.003 \\
\hline & ACTN2 & NM_001103 & -1.23 & 0.213 \\
\hline & ACTN3 & NM_001104 & -1.02 & 0.812 \\
\hline & ACTN4 & NM_004924 & 1.07 & 0.590 \\
\hline & LONP1 & NM_001276479 & -1.17 & 0.235 \\
\hline & $A L K B H 1$ & NM_006020 & -1.27 & 0.046 \\
\hline \multicolumn{5}{|l|}{ Downstream regulators } \\
\hline \multirow[t]{5}{*}{ Canonical pathway } & HES1 & NM_005524 & -1.12 & 0.119 \\
\hline & HEY1 & NM_001040708 & 1.09 & 0.317 \\
\hline & MYC & NM_002467 & -1.02 & 0.841 \\
\hline & $B C L 2$ & NM_000633 & 1.24 & 0.024 \\
\hline & CCND1 & NM_053056 & 1.38 & 0.031 \\
\hline \multirow[t]{7}{*}{ Non-canonical pathway } & CHUK & NM_001278 & 1.25 & 0.138 \\
\hline & NFKB1 & NM_001165412 & 1.18 & 0.124 \\
\hline & PIKЗСА & NM_006218 & 1.11 & 0.457 \\
\hline & AKT1 & NM_001014431 & 1.12 & 0.338 \\
\hline & AKT2 & NM_001243027 & 1.07 & 0.107 \\
\hline & AKT3 & NM_001206729 & -1.02 & 0.884 \\
\hline & CTNNB1 & NM_001098209 & 1.10 & 0.570 \\
\hline Lysosomal degradation & NUMB & NM_001005743 & 1.11 & 0.406 \\
\hline
\end{tabular}

HDLI, humidifier disinfectant lung injuries.

Upstream regulators are predicted using Ingenuity Pathway Analysis. Downstream regulators of NOTCH1 are notified from (https://www.rndsystems.com/pathways/notch-signaling-pathway). Formalin-Fixed Paraffin-Embedded lung tissue specimens from HDLI cases ( $n=5)$ and controls ( $n=5)$.

Our study had some limitations, including its small sample size. However, the results of the current study are significant in that HDLI is an exceptional disease, and the acquisition of blood and lung tissue in our patients was not easy. In our present cohort, there were time lags with a mean of 9 years between diagnosis of HDLI and blood sampling. The methylation patterns in the blood obtained after a time lag of 9 years may have been affected by diverse factors. ${ }^{16}$ A previous study showed that less than $30 \%$ of individuals showed methylation changes in epigenome-wide DNA methylation analysis on average 11 years apart, even with intra-individual variations. ${ }^{16}$ We could not perform methylation analysis in human lung tissues in the current study, as these samples were not available. In spite of the limitations, methylation changes observed in the present study could be helpful to elucidate the mechanisms underlying HDLI with stable disease state.

In conclusion, we have identified NOTCH1 pathways as one of the possible main fibrogenetic mechanisms of HDLI in children following exposure to PHMG phosphate. Further identification and elucidation of the mechanisms underlying this fatal lung disease are essential for the future development of therapeutics and prevention of lung diseases after exposure to harmful domestic chemicals.

\section{ACKNOWLEDGEMENTS}

This study was funded by the Korea Ministry of Environment (MOE) as "the Environmental Health Action Program (2016001360006)" and partially supported by the Environmental Health Center for Hazardous Chemical Exposure funded by the Ministry of Environment Republic of Korea (2019).

\section{AUTHOR CONTRIBUTIONS}

Conceptualization: Eun Lee, Mi Jin Kang, Jeong-Hyun Kim, and SooJong Hong. Data curation: Seung-Hwa Lee, So-Yeon Lee, Hyun-Ju Cho, Jisun Yoon, Sungsu Jung, Yangsoon Park, Dong Kyu Oh, and Sang-Bum Hong. Formal analysis: Mi Jin Kang and Jeong-Hyun Kim. Funding acquisition: Eun Lee and Soo-Jong Hong. Investigation: Eun Lee, Mi Jin Kang, Jeong-Hyun Kim, Dong Kyu Oh, Sang-Bum Hong, and Soo-Jong Hong. Methodology: Mi Jin Kang, Jeong-Hyun Kim, Seung-Hwa Lee, and Yangsoon Park. Project administration: Eun Lee, Mi Jin Kang, Jeong-Hyun Kim, and Soo-Jong Hong. Resources: Eun Lee and Soo-Jong Hong. Software: Mi Jin Kang and Jeong-Hyun Kim. Supervision: Soo-Jong Hong. Validation: Eun Lee, Mi Jin Kang, Jeong-Hyun Kim, Seung-Hwa Lee, and Yangsoon Park. Writing-original draft: Eun Lee. Writing - review \& editing: Eun Lee, Jeong-Hyun Kim, and Soo-Jong Hong. Approval of final manuscript: all authors. 


\section{ORCID iDs}

Eun Lee

Mi Jin Kang Jeong-Hyun Kim

Seung-Hwa Lee

So-Yeon Lee

Hyun-Ju Cho

Jisun Yoon

Sungsu Jung

Yangsoon Park

Dong Kyu Oh

Sang-Bum Hong

Soo-Jong Hong https://orcid.org/0000-0002-0145-7067 https://orcid.org/0000-0001-8510-3268 https://orcid.org/0000-0003-4879-0075 https://orcid.org/0000-0001-9359-0318 https://orcid.org/0000-0002-2499-0702 https://orcid.org/0000-0003-4282-4000 https://orcid.org/0000-0002-4904-9118 https://orcid.org/0000-0002-0559-4982 https://orcid.org/0000-0003-2832-3525 https://orcid.org/0000-0002-7511-9634 https://orcid.org/0000-0003-2737-7695 https://orcid.org/0000-0003-1409-2113

\section{REFERENCES}

1. Kim KW, Ahn K, Yang HJ, Lee S, Park JD, Kim WK, et al. Humidifier disinfectant-associated children's interstitial lung disease. Am J Respir Crit Care Med 2014;189:48-56.

2. Hong SB, Kim HJ, Huh JW, Do KH, Jang SJ, Song JS, et al. A cluster of lung injury associated with home humidifier use: clinical, radiological and pathological description of a new syndrome. Tho$\operatorname{rax} 2014 ; 69: 694-702$.

3. Ryu SH, Park DU, Lee E, Park S, Lee SY, Jung S, et al. Humidifier disinfectant and use characteristics associated with lung injury in Korea. Indoor Air 2019;29:735-47.

4. Park DU, Ryu SH, Lim HK, Kim SK, Choi YY, Ahn JJ, et al. Types of household humidifier disinfectant and associated risk of lung injury (HDLI) in South Korea. Sci Total Environ 2017;596-597:53-60.

5. Yoon J, Cho HJ, Lee E, Choi YJ, Kim YH, Lee JL, et al. Rate of humidifier and humidifier disinfectant usage in Korean children: a nationwide epidemiologic study. Environ Res 2017;155:60-3.

6. Yang IV, Pedersen BS, Rabinovich E, Hennessy CE, Davidson EJ,

Murphy E, et al. Relationship of DNA methylation and gene expression in idiopathic pulmonary fibrosis. Am J Respir Crit Care Med 2014;190:1263-72.

7. Sanders YY, Ambalavanan N, Halloran B, Zhang X, Liu H, Crossman DK, et al. Altered DNA methylation profile in idiopathic pulmonary fibrosis. Am J Respir Crit Care Med 2012;186:525-35.

8. Zong D, Ouyang R, Li J, Chen Y, Chen P. Notch signaling in lung diseases: focus on Notch1 and Notch3. Ther Adv Respir Dis 2016; 10:468-84.

9. Jiang J, Xiao K, Chen P. NOTCH signaling in lung diseases. Exp Lung Res 2017;43:217-28.

10. Kage H, Borok Z. EMT and interstitial lung disease: a mysterious relationship. Curr Opin Pulm Med 2012;18:517-23.

11. Yin Q, Wang W, Cui G, Yan L, Zhang S. Potential role of the Jaggedl/ Notch1 signaling pathway in the endothelial-myofibroblast transition during BLM-induced pulmonary fibrosis. J Cell Physiol 2018; 233:2451-63.

12. Li T, Yang X, Xin S, Cao Y, Wang N. Paraquat poisoning induced pulmonary epithelial mesenchymal transition through Notch1 pathway. Sci Rep 2017;7:924.

13. Liu T, Hu B, Choi YY, Chung M, Ullenbruch M, Yu H, et al. Notch1 signaling in FIZZ1 induction of myofibroblast differentiation. Am J Pathol 2009;174:1745-55.

14. Shin DY, Jeong MH, Bang IJ, Kim HR, Chung KH. MicroRNA regulatory networks reflective of polyhexamethylene guanidine phosphate-induced fibrosis in A549 human alveolar adenocarcinoma cells. Toxicol Lett 2018;287:49-58.

15. Jeong MH, Kim HR, Park YJ, Chung KH. Akt and Notch pathways mediate polyhexamethylene guanidine phosphate-induced epithelial-mesenchymal transition via ZEB2. Toxicol Appl Pharmacol 2019;380:114691.

16. Gervin K, Andreassen BK, Hjorthaug HS, Carlsen KCL, Carlsen $\mathrm{KH}$, Undlien DE, et al. Intra-individual changes in DNA methylation not mediated by cell-type composition are correlated with aging during childhood. Clin Epigenetics 2016;8:110. 